Фармацевтичний менеджмент, маркетинг та логістика

Pharmaceutical management, marketing and logistics

Рекомендована д. фрармац. наук, проф. В. В. Трохимчуком

УДК 608.3+347.77

\title{
АНАЛІЗ ОСОБЛИВОСТЕЙ ПАТЕНТНО-ІННОВАЦІЙНОЇ СТРАТЕГІЇ ПРИ СТВОРЕННІ ОРФАННИХ ПРЕПАРАТІВ
}

\author{
()О. В. Літвінова \\ Національний фрармацевтичний університет, Харків
}

\begin{abstract}
Резюме: проаналізовано питання, які пов'язані зі створенням, фрінансуванням, використанням орфанних препаратів та їх вартістю. Охарактеризовано правові норми зарубіжних регулюючих органів, які спрямовані на розвиток лікарських засобів для лікування рідкісних захворювань. Продемонстровано, що державна підтримка, патенти на винаходи і положення щодо ексклюзивності даних клінічних випробувань є основними підходами до надання стимулів для інноваційних біофармацевтичних досліджень і розробок при створенні орфанних препаратів. Запропоновано алгоритм патентно-інноваційної стратегії при створенні орфанних препаратів.
\end{abstract}

Ключові слова: орфанні препарати, патент, інновації, ексклюзивність, інтелектуальні ресурси.

Вступ. Однією з проблем вітчизняної фрармації, яка розглядається сьогодні, $є$ створення препаратів для лікування рідкісних захворювань (так званих орфанних препаратів), їх фрінансування, особливості державної реєстрації та патентування.

Вперше термін орфанні («сирітські») захворювання і орфанні препарати з'явився в 1983 р. в законодавчому акті США «Orphan Drug Act». Зазначеним актом до таких захворювань віднесено близько 1600 захворювань і синдромів. Через 17 років подібний закон був розроблений і підписаний в Європейському Союзі. Американські та Європейські законодавці легалізували статус «орфанного» препарату і визначили параметри для його присвоєння. Так, в Європейському Союзі до таких захворювань відносять захворювання, які зустрічаються не більше 5 випадків на 1000 населення [1].

За даними міжнародних експертів, у світі існує 5-7 тисяч небезпечних для життя рідкісних захворювань. Більше 80 \% захворювань-сиріт $є$ генетично зумовленими [2]. За статистичними даними в Україні, як і в усьому світі, також реєструються орфанні захворювання: 1 випадок муковісцидозу реєструється на 2300 новонароджених; 1 випадок гемофрілії - на 6500 новонароджених хлопчиків та ін. Однак в Україні не ведуться розробки орфанних препаратів, і до недавна їх державна реєстрація була утруднена.

На сьогодні для більшості країн, у тому числі і для України, проблема виявлення захворювань-сиріт та їх лікування залишається гострим і складним питанням. Серед них слід підкреслити недостатню кількість інформації за поширеністю цих захворювань, обмежені можливості діагностики, відсутність ліків або їх високу вартість. Перед фрармацевтичними компаніями стоїть питання про те, що ліки, які отримані за новітніми технологіями, використовуватиме мала кількість пацієнтів, і в результаті їх виробництво буде нерентабельним. Але за даними звіту «Orphan Drug Report 2014», частка орфанних препаратів у загальному обсязі продажів рецептурних лікарських засобів (за винятком генериків) до 2020 р. складе 19,1 \% (близько 176 млрд дол. США), при цьому середньорічний приріст в період 2014-2020 рр. в грошовому вираженні складе 10,5 \% [3].

Мета роботи - аналіз особливостей патентноінноваційної стратегії при створенні орфанних препаратів.

Методи дослідження Дослідження проводили 3 використанням баз даних у мережі Інтернет: Українського патентного відомства, патентного відомства Російської Федерації, Європейської патентної організації, патентного відомства США, Адміністрації по контролю за ліками і харчовими продуктами, Європейського агентства лікарських засобів (ЕМЕА), ДП «Державний експертний центр» МОЗ України, сайту МОЗ України.

Результати й обговорення. Завдяки державному регулюванню інноваційних процесів за кордоном щодо стимулюванню R\&D-розробок орфранних препаратів вдається поступово підвищити доступність та ефективність таких препаратів для пацієнтів 3 рідкісними захворюваннями. Так, за даними аналітичної компанії «Evaluate Pharma», обсяг продажів орфанних препаратів в США, ЄС та Японії буде впевнено збільшуватися до 2020 р. У топ-10 фрармацевтичних компаній за обсягом продажів орсанних препаратів в грошовому вираженні на світовому ринку в 2020 увійдуть компанії «Bristol-Myers Squibb», «Novartis», «Celgene», «Roche», «Pfizer», «Alexion Pharmaceuticals», «Sanofi», «Vertex Pharmaceuticals», «GlaxoSmithKline», «Merck \& Co» [3].

Як показав проведений аналіз, такий прорив щодо впровадження орфанних препаратів зумовлений тим, що у світовій практиці використовуються різні

ISSN 2312-0967. Фармацевтичний часопис. 2015. № 2 
види пільг, які стимулюють інноваційну діяльність при їх створенні. Наприклад, у США, Японії, Тайвані, Сінгапурі, Австралії та країнах Євросоюзу прийняті законодавчі акти для стимулювання науки та бізнесу щодо розробок і виробництва препаратів для лікування пацієнтів 3 рідкісними захворюваннями. Зокрема, фрармацевтичним компаніям-розробникам таких інноваційних препаратів надають повні пільги: можливість отримання фрінансової підтримки 3 державних фондів для проведення досліджень у сфері рідкісних захворювань, інфрормаційна та організаційна підтримка у створенні протоколів клінічних випробувань, включно маркетингову підтримку на строк від 5 до 10 років, повна або часткова оплата процедур отримання офріційного дозволу на застосування у медичній практиці препаратів-сиріт [2, 5].

Слід вказати на позитивний зарубіжний досвід у сорері реалізації спільних проектів, що фрінансуються за рахунок різних джерел, в результаті чого знижується ступінь інтелектуального ризику для кожного окремого інвестора. 3 метою розподілу інтелектуальних ризиків фрармацевтичні та біотехнологічні компанії використовують угоди зі злиття і поглинання.

В Україні проблеми зі створення, виробництва і лікування орфанними препаратами більш складні, ніж у зарубіжних країнах. Проведений аналіз показав, що до недавна такі препарати взагалі були відсутні на фрармацевтичному ринку України, тому що вітчизняні виробники їх не розробляли з ряду причин: через високу вартість розробки, високу вартість препарату, низьку потребу, нерентабельність їх виробництва, складність проведення доклінічного вивчення та клінічних випробувань, відсутність законодавчої бази 3 реєстрації таких препаратів. Все зазначене не стимулювало вітчизняні фрармацевтичні компанії їх виробляти, а Європейські країни їх реєструвати в Україні.

Враховуючи, що на території України орфанні препарати не виробляють та їх поставки здійснюють по- вністю 3-за кордону, створено порядок пільгової та прискореної реєстрації таких лікарських засобів (ЛЗ). Внесено зміни до закону України «Про лікарські засоби» (від 12 серпня 2014 р. № 1637-VII) щодо удосконалення порядку забезпечення населення ЛЗ, які призначені для лікування соціально небезпечних і тяжких захворювань. Передбачена спрощена реєстрація в Україні протягом 7 діб л3, що зареєстровані компетентним органом США, ЄС, а саме ЛЗ, які призначені для лікування таких соціально небезпечних хвороб, як туберкульоз, ВІЛ/СНІД, вірусні гепатити, онкологічні, рідкісні (орфанні) захворювання.

Не підлягає сумніву той факт, що запорукою успіху створення і виробництва орфанних препаратів $€$ наявність дієвої системи патентного захисту. Слід зазаначити, що крім 25 років дії майнових прав патенту на Л3, існує режим «ексклюзивності даних», який визначається 3 дати першого маркетингового дозволу (ліцензія, що надається регулюючим органом, перед виведенням на ринок будь-якого медичного продукту). Якщо термін дії ексклюзивності даних знаходиться в межах 20 років патентної охорони, то це не стосується термінів виведення генеричних ЛЗ на ринок. Проте якщо перший маркетинговий дозвіл на реалізацію отриманий в кінці 20-річного терміну дії патенту, то при цьому термін охорони ЛЗ подовжується на термін дії «ексклюзивності». Таким чином, патентний захист та ексклюзивність даних незалежні один від одного і можуть не збігатися в часі. Режим «ексклюзивності» компенсує компанії-розробнику величезні витрати на клінічні випробування оригінальних ЛЗ, тоді як генеричні компанії виконують тільки дослідження з біоеквівалентності. Режими ексклюзивності в США та ЄС наведені в таблиці 1 [4].

Слід зазначити, що у даний час в Україні режим ексклюзивності не враховує особливості лікарських препаратів для лікування рідкісних захворювань. Термін дії охорони клінічних даних однаковий для всіх

Таблиця 1. Режими ексклюзивності в США та ЄС

\begin{tabular}{|l|l|}
\hline \multicolumn{1}{|c|}{ США } & \multicolumn{1}{|c|}{ ЄС } \\
\hline - для препаратів, які містять як діючу речовину, новий & - 10-річний період для високотехнологічних \\
АФІ, - 5 років; & препаратів; \\
- для препаратів для лікування рідкісних захворювань & - мінімальний 6-річний період для всіх інших \\
- 7 років; & препаратів; \\
- для відомих препаратів при повідомленні про & - 6-річний період, який припиняється після \\
нові клінічні дослідження (нові дозування, способи & закінчення терміну патентного захисту: деякі країни- \\
введення і показання) - 3-річний період; & члени вважали за краще поширювати ринкову \\
- для препаратів для педіатрії -6 місяців; & ексклюзивність тільки відносно запатентованих \\
- компанія, яка першою отримала дозвіл на маркетинг & препаратів; \\
генеричного препарату - 180 днів після закінчення дії & - необов'язковий 10-річний період, який можуть \\
терміну патентного захисту. & використовувати країни-члени на користь охорони \\
\multicolumn{2}{|c|}{} \\
& здоров'я для всіх препаратів, які зареєстровані на їх \\
& території; \\
& для препаратів для педіатрії - 6 місяців; \\
& для препаратів для лікування рідкісних захворювань \\
& термін ексклюзивності даних подовжується на 2 роки \\
& зверху звичайних 10 років. \\
\hline
\end{tabular}

ISSN 2312-0967. Pharmaceutical review. 2015. № 2 
Фармацевтичний менеджмент, маркетинг та логістика Pharmaceutical management, marketing and logistics

груп препаратів і становить 5 років, що відображене в статті 9 Закону України "Про лікарські засоби".

Проведено аналіз патентної стратегії на прикладі ряду зарубіжних фрармацевтичних компаній, які за даними Державного експертного центру МОЗ України зареєстрували орфанні препарати на підставі заяви на реєстрацію ЛЗ обмеженого застосування (препарату-сироти) (станом на 30.10.2014) (табл. 2).
Проведений аналіз виявив потужну патентну охорону орфанних препаратів, які часто захищаються декількома патентами на території ряду країн. Так, у ряді випадків виявлено подачу до 52 патентних заявок на один препарат. Закінчення строку дії ряду патентів на орфанні препарати припадає на 2025 р. Слід враховувати використання режиму ексклюзивності для вказаних препаратів за кордоном. Зазна-

Таблиця 2. Дані про патентну охорону деяких зареєстрованих зарубіжних орфанних препаратів в Україні

\begin{tabular}{|c|c|c|c|c|c|c|}
\hline № & $\begin{array}{c}\text { Торговельне } \\
\text { найменування, } \\
\text { МНН, } \\
\text { лік. фрорма }\end{array}$ & $\begin{array}{c}\text { N патенту } \\
\text { США; кількість } \\
\text { патентів- } \\
\text { аналогів }\end{array}$ & $\begin{array}{c}\text { Дата } \\
\text { закінчення } \\
\text { терміну дії } \\
\text { патенту }\end{array}$ & $\begin{array}{c}\text { Клініко-фрармакологічна } \\
\text { група АТС }\end{array}$ & $\begin{array}{c}\text { Задеклар. } \\
\text { оптово- } \\
\text { відп. ціна } \\
\text { упаковки }{ }^{1}, \\
\text { грн } \\
\end{array}$ & Виробник, країна \\
\hline 1 & 2 & 3 & 4 & 5 & 6 & 7 \\
\hline 1 & $\begin{array}{l}\text { Адцетрис } \\
\text { brentuximab, } \\
\text { vedotin, } \\
\text { пор.д/iн. } \\
\end{array}$ & $\begin{array}{l}\text { US7829531; } 39 \\
\text { US7090843; } 39\end{array}$ & $\begin{array}{l}31.12 .2029 \\
15.08 .2026\end{array}$ & $\begin{array}{l}\text { Антинеопластичні } \\
\text { засоби. Моноклональні } \\
\text { антитіла. L01XC12 }\end{array}$ & $55902,26^{*}$ & $\begin{array}{l}\text { БСП Фарма- } \\
\text { сьютікалз, } \\
\text { Такеда Італія/ } \\
\text { Франція } \\
\end{array}$ \\
\hline 2 & $\begin{array}{l}\text { Гліолан, } \\
\text { aminolevulinic } \\
\text { acid, пор.д/op. } \\
\text { p-ну }\end{array}$ & \begin{tabular}{|l} 
US5954703; 18 \\
US6709446; 32 \\
US7723910; 32 \\
US8216289; 32 \\
US8758418; 32 \\
\end{tabular} & \begin{tabular}{|l|}
31.10 .2017 \\
01.05 .2018 \\
17.06 .2019 \\
01.05 .2018 \\
01.05 .2018 \\
\end{tabular} & $\begin{array}{l}\text { Сенсибілізуючі засоби } \\
\text { для застосування у } \\
\text { фотодинамічній/проме- } \\
\text { невій терапії. L01XD04 }\end{array}$ & $\begin{array}{l}\text { Дані не } \\
\text { виявлені }\end{array}$ & $\begin{array}{l}\text { Медак Гмбх, } \\
\text { Німеччина }\end{array}$ \\
\hline 3 & $\begin{array}{l}\text { Джакаві, } \\
\text { ruxolitinib, } \\
\text { табл. }\end{array}$ & \begin{tabular}{|l} 
US7598257; 52 \\
US8415362; 52 \\
US8722693; 35 \\
US8822481; 35 \\
US8829013; 35 \\
\end{tabular} & $\begin{array}{l}24.12 .2027 \\
24.12 .2027 \\
12.06 .2028 \\
12.06 .2028 \\
12.06 .2028 \\
\end{array}$ & $\begin{array}{l}\text { Антинеопластичні } \\
\text { засоби. Інгібітори } \\
\text { протеїнкінази. L01XE18 }\end{array}$ & $67452,66^{\star}$ & $\begin{array}{l}\text { Новартіс Фарма } \\
\text { Штейн АГ, } \\
\text { Швейцарія }\end{array}$ \\
\hline 4 & $\begin{array}{l}\text { Елапраза, } \\
\text { idursulfase, } \\
\text { конц. д/інфр. }\end{array}$ & US5932211; 5 & 28.11 .2015 & $\begin{array}{l}\text { Засоби, що впливають } \\
\text { на систему травлення } \\
\text { та метаболізм. } \\
\text { Ферменти. А16АВ09 }\end{array}$ & 46603,87 & $\begin{array}{l}\text { Шайєр Хьюмен } \\
\text { Дженетік Терапіс } \\
\text { АБ, Швеція/США }\end{array}$ \\
\hline 5 & $\begin{array}{l}\text { Куван, } \\
\text { sapropterin, } \\
\text { табл. розчин. }\end{array}$ & \begin{tabular}{|l|} 
US7566462; 17 \\
US7566714; 14 \\
US7612073; 34 \\
US7727987; 15 \\
US7947681; 34 \\
US8003126; 17 \\
US8067416;14 \\
US8318745; 15 \\
\end{tabular} & \begin{tabular}{|l|}
16.05 .2026 \\
17.05 .2025 \\
17.05 .2025 \\
17.05 .2025 \\
17.05 .2025 \\
17.05 .2025 \\
17.05 .2025 \\
17.05 .2025 \\
\end{tabular} & $\begin{array}{l}\text { Засоби, що впливають } \\
\text { на систему травлення } \\
\text { та метаболізм. } \\
\text { А16АХ07 }\end{array}$ & 17946,90 & $\begin{array}{l}\text { Екселла ГмбХI } \\
\text { Мерк, Німеччина/ } \\
\text { Австрія }\end{array}$ \\
\hline 6 & $\begin{array}{l}\text { Мепакт, } \\
\text { mifamurtide, } \\
\text { пор. д/сусп. д/ } \\
\text { iнфр. } \\
\end{array}$ & US4971802; 22 & 20.11 .2010 & $\begin{array}{l}\text { Антинеопластичні та } \\
\text { iмуномодулюючі засоби. } \\
\text { Інші імуно-стимулятори. } \\
\text { L03A X15 }\end{array}$ & $\begin{array}{l}\text { Дані не } \\
\text { виявлені }\end{array}$ & $\begin{array}{l}\text { БСП Фарма- } \\
\text { сьютікалз, } \\
\text { Такеда Італія/ } \\
\text { Франція } \\
\end{array}$ \\
\hline 7 & $\begin{array}{l}\text { Miозим } \\
\text { alglucosidase } \\
\text { alfa, пор. д/п } \\
\text { конц. д/р-ну д/ } \\
\text { iнфр. } \\
\end{array}$ & $\begin{array}{l}\text { US6118045; } 42 \\
\text { US7351410; } 42 \\
\text { US7655226; } 42\end{array}$ & $\begin{array}{l}18.08 .2018 \\
29.10 .2020 \\
16.12 .2019\end{array}$ & $\begin{array}{l}\text { Засоби, що впливають } \\
\text { на систему травлення } \\
\text { та метаболізм. } \\
\text { Ферменти. А16АВ07 }\end{array}$ & $\begin{array}{l}\text { Дані не } \\
\text { виявлені }\end{array}$ & \begin{tabular}{|l} 
Джензайм \\
Фландерс бвба \\
Бельгія/США/ \\
Ірландія/Велика \\
Британія \\
\end{tabular} \\
\hline 8 & $\begin{array}{l}\text { Наглазим, } \\
\text { galsulfase, } \\
\text { конц. д/p-ну д/ } \\
\text { iнфр. } \\
\end{array}$ & US6866844; 23 & 07.11 .2022 & $\begin{array}{l}\text { Засоби, що впливають } \\
\text { на систему травлення } \\
\text { та метаболізм. Фермен- } \\
\text { ти. А16АВ08 }\end{array}$ & 22575,13 & \begin{tabular}{|l} 
Джубілант \\
ХоллістерСтер \\
СшА/Німеччина/ \\
Велика Британія \\
\end{tabular} \\
\hline 9 & $\begin{array}{l}\text { Ордадин, } \\
\text { nitisinone, } \\
\text { капс. }\end{array}$ & US5550165; 10 & 27.08 .2013 & $\begin{array}{l}\text { Інші засоби, що } \\
\text { впливають на } \\
\text { систему травлення та } \\
\text { метаболізм. А16АХ04 }\end{array}$ & $\begin{array}{l}\text { Дані не } \\
\text { виявлені }\end{array}$ & $\begin{array}{l}\text { Апотек Продакшн } \\
\& \text { Леборетріер АБ } \\
\text { Швеція }\end{array}$ \\
\hline
\end{tabular}

ISSN 2312-0967. Фармацевтичний часопис. 2015. № 2 
Фармацевтичний менеджмент, маркетинг та логістика Pharmaceutical management, marketing and logistics

Продовження табл. 2

\begin{tabular}{|c|c|c|c|c|c|c|}
\hline 1 & 2 & 3 & 4 & 5 & 6 & 7 \\
\hline 10 & $\begin{array}{l}\text { Пульмозим, } \\
\text { dornase alfa } \\
\text { (desoxyribo- } \\
\text { nuclease), } \\
\text { р-н д/інг. }\end{array}$ & US6383788 & 28.02 .2015 & $\begin{array}{l}\text { Муколітичні } \\
\text { засоби. R05СВ13 }\end{array}$ & 1905,94 & $\begin{array}{l}\text { Дженентек Інк. /Ф. } \\
\text { Хоффрманн- } \\
\text { Ля Рош Лтд/ } \\
\text { Кетелент Фарма } \\
\text { Солюшнз } \\
\text { США/Швейцарія/ } \\
\text { Німеччина }\end{array}$ \\
\hline 11 & $\begin{array}{l}\text { Сигнісрор, } \\
\text { pasireotide, } \\
\text { p-н д/ін. }\end{array}$ & $\begin{array}{l}\text { US6225284; } 32 \\
\text { US7473761; } 39\end{array}$ & $\begin{array}{l}28.06 .2016 \\
27.12 .2025\end{array}$ & \begin{tabular}{|l|} 
Гіпофізарні, \\
гіпоталамічні гормони та \\
їх аналоги. Н01СВ05
\end{tabular} & 38035,80 * & $\begin{array}{l}\text { Новартіс Фарма } \\
\text { Штейн АГ } \\
\text { Швейцарія } \\
\end{array}$ \\
\hline 12 & $\begin{array}{l}\text { Сурванта } \\
\text { beractant, } \\
\text { сусп. д/інтра- } \\
\text { трахеал. введ. }\end{array}$ & US4397839; 3 & 05.07 .2001 & $\begin{array}{l}\text { Легеневі сурфактанти. } \\
\text { Комбінації. } \\
\text { R07AA30 }\end{array}$ & 7141,66 & $\begin{array}{l}\text { Еббві Інк. } \\
\text { США }\end{array}$ \\
\hline 13 & $\begin{array}{l}\text { Треосульфан } \\
\text { медак, } \\
\text { treosulfan, } \\
\text { пор. д/п інфр. } \\
\text { р-ну }\end{array}$ & US7199162; 17 & 05.11 .2019 & $\begin{array}{l}\text { Антинеопластичні } \\
\text { засоби. Алкілуючі } \\
\text { сполуки. } \\
\text { L01AB02 }\end{array}$ & 2678,66 & $\begin{array}{l}\text { Медак гмбХ, } \\
\text { Німеччина }\end{array}$ \\
\hline 14 & $\begin{array}{l}\text { Фабразим, } \\
\text { agalsidase beta, } \\
\text { пор. д/п конц. } \\
\text { д/р-ну д/інор. }\end{array}$ & US5356804; 38 & 27.09 .2015 & $\begin{array}{l}\text { Засоби, що впливають } \\
\text { на систему травлення } \\
\text { та метаболізм. } \\
\text { Ферменти. А16АВ04 } \\
\end{array}$ & $\begin{array}{l}\text { Дані не } \\
\text { виявлені }\end{array}$ & $\begin{array}{l}\text { Джензайм Лтд/ } \\
\text { Хоспіра Інк. } \\
\text { Сполучене } \\
\text { Королівство/США }\end{array}$ \\
\hline
\end{tabular}

Примітки: ${ }^{1}$ - задекларована оптово-відпускна ціна упаковки (грн) станом на 13.02.2015 р.

* - оптова ціна.

чене дозволяє закордонним компаніям-розробникам ексклюзивний продаж протягом тривалого періоду, що покращує їх комерційні перспективи. Великі фрармацевтичні фрірми розглядають розробку орфанних препаратів ще й як свого роду можливість виявлення нових інноваційних розробок у суміжних областях.

Основними об'єктами для патентування орфанних препаратів є: активний фрармацевтичний інгредієнт (АФІ), фрармацевтична композиція, способи отримання АФІ або фрармацевтичної композиції, способи лікування.

Як наслідок, в умовах конкуренції патенти на орфанні препарати забезпечують монопольне право фармацевтичним компаніям на виробництво інноваційних препаратів.

Проведений аналіз також виявив, що задекларована оптово-відпускна ціна упаковки орфанних препаратів знаходиться у діпазоні 1905,94-67452,66 грн. Зазначені препарати застосовуються для лікування онкозахворювань, порушеного метаболізму, які, як правило, вимагають тривалої підтримуючої терапії. Крім того, застосування препаратів-сиріт є єдиною можливістю корекції патології у хворих з орфанними хворобами. Але така вартість курсу лікування недоступна хворим із рідкісними захворюваннями, їм потрібна державна підтримка. Слід зазначити, що в Іспанії, Італії, Португалії, Голландії з бюджетів країн виділяється понад 100 млрд євро на ліки для лікування даної категорії хворих.

В Україні створюється нормативно-правова база щодо забезпечення профрілактики та лікування орфанних захворювань. Згідно з законом України (від 15 квітня 2014 р. №1213-VII) «Про внесення змін до Основ законодавства України про охорону здоров'я щодо забезпечення профрілактики та лікування рідкісних (орфанних) захворювань», громадяни, які хворіють на рідкісні (орфанні) захворювання, безперебійно та безоплатно забезпечуватимуться необхідними для терапії цих захворювань ліками та відповідними харчовими продуктами для спеціального дієтичного споживання.

3 метою оцінки економічних витрат на лікування таких хворих необхідне створення персоніфікованих регістрів рідкісних захворювань. Зазначеним вище законом України регламентується забезпечити створення та ведення державного реєстру громадян, які страждають на рідкісні (орфанні) захворювання.

Проведений аналіз, систематизація даних літературних джерел дозволили запропонувати авторський алгоритм здійснення патентно-інноваційної стратегії при створенні орфранних препаратів (рис. 1).

Раціональна патентно-інноваційна стратегія при створенні орфанних препаратів зарубіжними компаніями дозволяє досягти значного прогресу у вирішенні проблеми лікування рідкісних захворювань та їх доступності для пацієнтів. Так, у 2014 р. EMEA рекомендувало до схвалення 82 орфанних препаратів. Серед них 17 призначені для терапії хворих 3 рідкісними патологіями, забезпечуючи можливість лікування для пацієнтів, які не мають зовсім або мають тільки кілька варіантів терапії [6].

ISSN 2312-0967. Pharmaceutical review. 2015. № 2 
Принципи та форми патентно-інноваційної політики при створенні орфанних препаратів

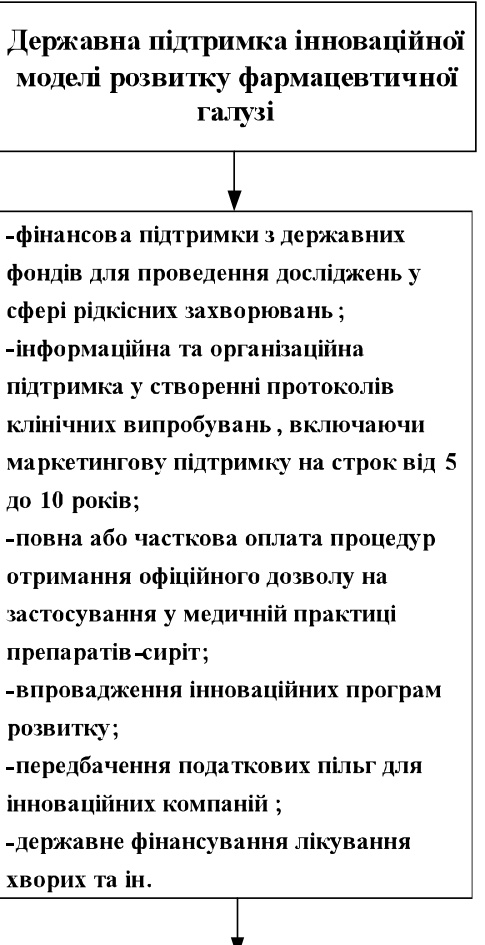

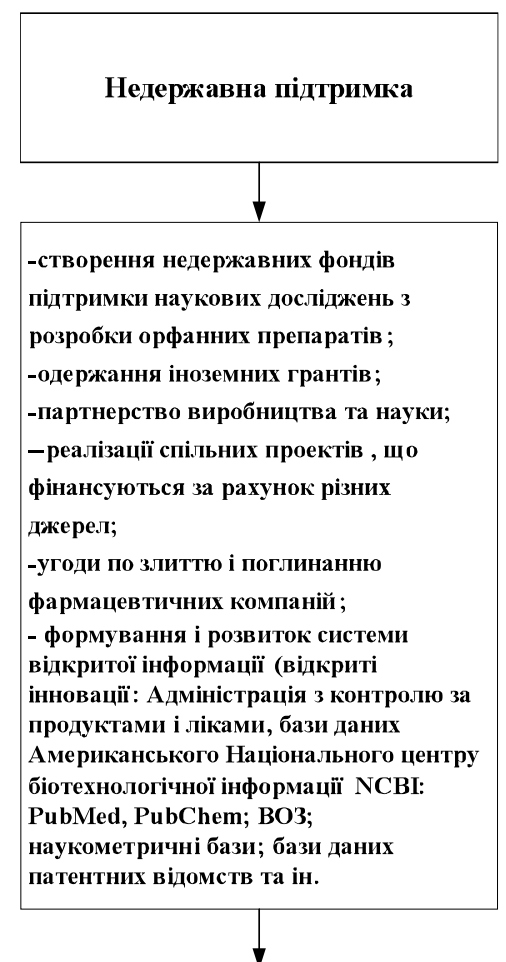

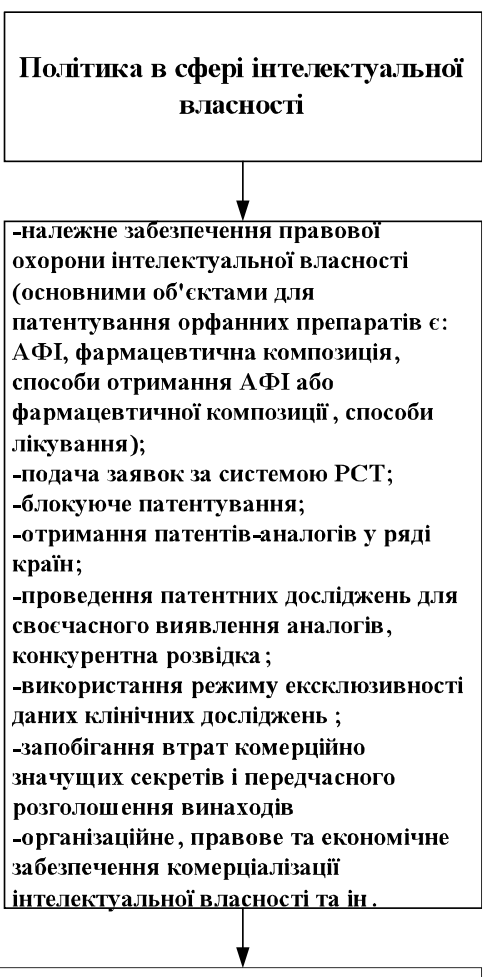

Оцінка досягнення поставлених цілей та реалізації стратегії інноваційного розвитку при створенні орфанних препаратів

Рис. 1. Алгоритм здійснення патентно-інноваційної стратегії при створенні орфранних препаратів.

Тим не менш, до остаточного вирішення даної проблеми навіть у світовому масштабі ще далеко. Сьогодні налічується близько 5-7 тис. різних рідкісних захворювань, з яких всього лише для 1\% в ЄС схвалені лікарські засоби. Тому робота за стимулювання створення нових орфанних препаратів ще далека від завершення, отже, ринок лікарських засобів володіє значними резервами для росту і розвитку, у тому числі і для фрармацевтичного ринку України, оскільки поки вітчизняні підприємства не виробляють препаратів для лікування рідкісних захворювань.

Висновки. 1. Регулювання інноваційних процесів за кордоном щодо стимулювання створення орфанних препаратів дозволило підвищити їх доступність та ефрективність в країнах Європи, США, Японії та ін.

2. Законодавча база України прийняла прискорену і спрощену процедуру реєстрації орфранних препаратів, що відповідає Європейським вимогам. Зазначене дозволить збільшити кількість зареєстрованих зарубіжних препаратів для лікування рідкісних захворювань в Україні. Однак вартість курсу лікування недоступна хворим, потрібна державна підтримка.

3. Створення орфанних препаратів належить до найбільш наукомістких галузей фрармації, які активно розвиваються, що вимагає раціонального управління інтелектуальними ресурсами і наявності дієвої системи патентного захисту. Патентно-інноваційна стратегія при створенні орфранних препаратів передбачає: формування патентного портореля для їх розробки у ряді країн, використання режиму ексклюзивності, надання державної підтримки при проведенні їх наукових досліджень.

4. Запропоновано алгоритм патентно-інноваційної стратегії при створенні орфанних препаратів, який враховує державну та недержавну підтримку інноваційної моделі розвитку фрармацевтичної галузі, особливості політики щодо інтелектуальної власності.

\section{Література}

1. Ченцова М. Мировой рынок орфанных препаратов / М. Ченцова // Ремедиум - 2007. - № 9. - С. 11-15.

2. Tiwari J. Navigating through orphan medicinal product regulations in EU and US / Tiwari J. // Similarities and

ISSN 2312-0967. Фармацевтичний часопис. 2015. № 2 
Фармацевтичний менеджмент, маркетинг та логістика

Pharmaceutical management, marketing and logistics

differences. Regul Toxicol Pharmacol. - 2015. - № 71(1). - P. 63-67.

3. Шелепко С. Мировой рынок орфанных препаратов: что имеем и каков прогноз? / С. Шелепко // Аптека 2015. - № 9. - [Електронний ресурс]. - Режим доступу: www.apteka.ua - Заголовок з екрану.

4. Літвінова, О. В. Актуальні проблеми захисту даних клінічних випробувань як об'єкту інтелектуальної власності у фрармацевтичній галузі / О. В. Літвінова, Н. Ф. Маслова // Фармаком - 2011. - № 1-2. - С. 93-96.
5. Grabowski H. G. The roles of patents and research and development incentives in biopharmaceutical innovation / H. G. Grabowski, J. A. DiMasi, G. Long // Health Aff (Millwood). - 2015 - № 34 (2). - P. 302-310.

6. В 2014г. ЕМА рекомендовано к одобрению рекордное количество лекарственных средств для терапии пациентов с редкими заболеваниями // Аптека - 2015. - № 1 (972). - [Електронний ресурс]. - Режим доступу: www.apteka.ua - Заголовок 3 екрану.

\title{
АНАЛИЗ ОСОБЕННОСТЕЙ ПАТЕНТНО-ИННОВАЦИОННОЙ СТРАТЕГИИ ПРИ СОЗДАНИИ ОРФАННЫХ ПРЕПАРАТОВ
}

\section{Е. В. Литвинова}

\author{
Национальный фрармацевтический университет, Харьков
}

Резюме: проанализированы вопросы, связанные с созданием, фринансированием, использованием орфанных препаратов и ихстоимостью. Охарактеризованы правовые нормызарубежных регулирующих органов, направленные на развитие лекарственных средств для лечения редких заболеваний. Продемонстрировано, что государственная поддержка, патенты на изобретения и положение об эксклюзивности данных клинических испытаний являются основными подходами к предоставлению стимулов для инновационных биофармацевтических исследований и разработок при создании орфанных препаратов. Предложен алгоритм патентно-инновационной стратегии при создании орфанных препаратов.

Ключевые слова: орфанные препараты, патент, инновации, эксклюзивность, интеллектуальные ресурсы.

\section{ANALYSIS OF SPECIAL ASPECTS OF PATENT-INNOVATIVE STRATEGY FOR ORPHAN DRUG CREATION}

\section{O. V. Litvinova}

National University of Pharmacy, Kharkiv

Summary: there were analyzed the issues related to the creation, funding, use of orphan drugs and their cost. There were characterized the legal norms of foreign regulators to develop drugs for treatment of rare diseases. It was demonstrated that the state support, patents and exclusivity of clinical trials are the main approaches to the provision of incentives for innovative biopharmaceutical research and development in the field of orphan drugs. It has established the algorithm of patent innovation strategy for orphan drug creating.

Key words: orphan drugs, patent, innovation, exclusivity, intellectual resources. 